\title{
AMPA/Kainate Receptors Drive Rapid Output and Precise Synchrony in Olfactory Bulb Granule Cells
}

\author{
Nathan E. Schoppa \\ Department of Physiology and Biophysics, University of Colorado at Denver Health Sciences Center at Fitzsimons, Aurora, Colorado 80045
}

Gamma frequency $(30-70 \mathrm{~Hz})$ synchronized oscillatory activity in the olfactory bulb is widely believed to be important for odor detection and discrimination. As in other circuits with "gamma activity," the activity in the bulb is driven by GABAergic interneurons, specifically a class of axonless cells called granule cells. However, bulb granule cells appear to lack some key mechanistic features that promote rapid synchrony in other circuits, including direct electrical interconnections and dominant actions for fast neurotransmitter receptors. At least under "static" stimulus conditions, granule cells are driven by kinetically slow NMDA receptors. Here, I used patch-clamp recordings in rat olfactory bulb slices to better understand mechanisms that shape granule cell activity under "dynamic" stimulus conditions that mimic a natural odor stimulus. During a $4 \mathrm{~Hz}$ patterned stimulation of olfactory nerve afferents, activation of single granule cells was primarily controlled by two classes of AMPA/kainate receptor-mediated synaptic inputs derived from output mitral cells. The rapid kinetics of these receptors, together with inactivation of A-type potassium channels, ensured that granule cells had short spike-response times. Studies in cell pairs, moreover, indicated that excitatory inputs could synchronize granule cells on a rapid time scale (2-5 ms), in turn resulting in phase-locked GABA release onto mitral cells. The precision of granule cell synchrony was controlled by the same biophysical mechanisms that promoted rapid single-cell spiking. These studies demonstrate the mechanistic underpinnings that transform a circuit with slow, uncoupled activity under static conditions into a fast, dynamic circuit operating with high precision under physiological conditions.

Key words: olfactory; synchronization; AMPA receptor; GABAergic; interneuron; mitral cell; granule cell

\section{Introduction}

Synchronized oscillatory activity at gamma frequency $(30-70$ $\mathrm{Hz}$ ) is widely believed to be important for odor detection and discrimination (Mori et al., 1999; Laurent et al., 2001; Lledo et al., 2005). Mechanistically, "gamma activity" within the mammalian olfactory bulb depends on a class of axonless GABAergic interneurons called granule cells, which synchronize output mitral cells through inhibitory inputs (Rall and Shepherd, 1968; Friedman and Strowbridge, 2003; Lagier et al., 2004; Galan et al., 2006; Schoppa, 2006). Bulb granule cells, however, appear to lack some key mechanisms that promote rapid synchrony in many other circuits. For example, granule cells do not form direct electrical interconnections (Schoppa, 2006) of the type that augment gamma activity in the cortex and hippocampus (Galarreta and Hestrin, 1999; Gibson et al., 1999; Tamás et al., 2000; Hormuzdi et al., 2001; Traub et al., 2004). Also, whereas gamma activity in other circuits relies on kinetically fast AMPA (Fuchs et al., 2001) or $\mathrm{GABA}_{\mathrm{A}}$ receptor-mediated synaptic responses (Whittington et al., 1995; Traub et al., 1996; Bartos et al., 2002), synaptic excita-

\footnotetext{
Received Aug. 12, 2006; revised Nov. 7, 2006; accepted Nov. 7, 2006.

This work was supported by National Institutes of Health Grant R01 DC006640-01A1 (N.E.S.). I thank Dr. Ben Strowbridge and Ramani Balu for helpful discussions. I declare that I have no competing financial interests.

Correspondence should be addressed to Nathan E. Schoppa, Department of Physiology and Biophysics, University of Colorado at Denver Health Sciences Center at Fitzsimons, Mail Stop 8307, P.0. Box6511, Aurora, C0 80045. E-mail: Nathan.Schoppa@UCHSC.edu.

DOI:10.1523/JNEUROSCI.3503-06.2006

Copyright $\odot 2006$ Society for Neuroscience $\quad$ 0270-6474/06/2512996-11\$15.00/0
}

tion and inhibition in the bulb can persist for hundreds of milliseconds, reflecting the dominant action of kinetically slow NMDA receptors (Isaacson and Strowbridge, 1998; Schoppa et al., 1998; Urban and Sakmann, 2002).

A number of plausible explanations could account for the apparent mismatch between the observed gamma-network oscillations in the bulb and the cellular/synaptic properties of granule cells. One factor is that previous studies of granule cells have generally been done under "static" conditions (i.e., after a single stimulus of one or a small number of cells). A physiological odor stimulus, in contrast, activates many neurons across multiple breathing cycles. Under these "dynamic" conditions, the receptors and channels that govern bulb neurons may be markedly different, owing to processes such as channel inactivation. In addition, dynamic stimulation could introduce novel circuit mechanisms that appear only when networks are stimulated. For example, one recent study showed that a patterned stimulus that mimics the breathing cycle caused the appearance of synchronized synaptic events in granule cells that were presumed to reflect glutamatergic inputs from mitral cells (Schoppa, 2006). Dynamic stimulation could also activate Blanes cells in the bulb (Pressler and Strowbridge, 2006), which could synchronize granule cells through GABAergic inputs. Such "emergent" circuit mechanisms could subserve functions similar to direct interneuron-to-interneuron connections in other circuits.

In this study, I used whole-cell patch-clamp recordings from rat olfactory bulb slices to examine mechanisms that control the 
activity of granule cells when a $4 \mathrm{~Hz}$ patterned stimulus is applied to the olfactory nerve $(\mathrm{ON})$. There were three objectives. First, voltage-clamp recordings in single granule cells were used to categorize synaptic inputs received by granule cells under these conditions, both glutamatergic and GABAergic. Second, I tested how these inputs, together with intrinsic voltage-gated ion channels, shape granule cell activation. Third, recordings from cell pairs were used to examine how the biophysical properties identified in single cells impact coordination of spiking and GABA release in multiple granule cells.

\section{Materials and Methods}

Horizontal slices $(300-400 \mu \mathrm{m})$ were prepared from olfactory bulbs of 6- to 22-d-old Sprague Dawley rats, as described by Schoppa et al. (1998), and viewed under differential interference contrast optics (Axioskop; Carl Zeiss, Thornwood, NY). All experiments were approved by the Institutional Animal Care and Use Committee at the University of Colorado at Denver Health Sciences Center. In the granule cell recordings, cells were selected from the granule cell layer (GCL) based on their small cell-body diameters $(<10 \mu \mathrm{m})$ (Pressler and Strowbridge, 2006). Experiments were performed at $32-35^{\circ} \mathrm{C}$.

Electrophysiology. The base extracellular solution for all recordings contained (in mM) $125 \mathrm{NaCl}, 25 \mathrm{NaHCO}_{3}, 1.25 \mathrm{NaH}_{2} \mathrm{PO}_{4}, 25$ glucose, 3 $\mathrm{KCl}, 2 \mathrm{CaCl}_{2}, 1$ and $\mathrm{MgCl}_{2}, \mathrm{pH} 7.3$, and was oxygenated $\left(95 \% \mathrm{O}_{2}, 5 \%\right.$ $\mathrm{CO}_{2}$ ). The pipette solution for most granule cell recordings, except where noted, contained the following (in $\mathrm{mM}$ ): $125 \mathrm{~K}$-gluconate, $2 \mathrm{MgCl}_{2}, 0.025$ $\mathrm{CaCl}_{2}, 1$ EGTA, $2 \mathrm{Na}-\mathrm{ATP}, 0.5 \mathrm{Na}-\mathrm{GTP}$, and 10 HEPES, pH 7.3 with $\mathrm{KOH}$. In some voltage-clamp recordings in granule cells and mitral cells, $\mathrm{K}$-gluconate was replaced with $\mathrm{KCl}$ to augment $\mathrm{GABA}_{\mathrm{A}}$ receptormediated IPSCs. Current and voltage signals recorded with a MultiClamp 700A dual patch clamp (Molecular Devices, Sunnyvale, CA) were filtered at $2-5 \mathrm{kHz}$ using an eight-pole Bessel filter and digitized at 5-10 kHz. Data were acquired using Axograph software on a Macintosh G4. The membrane voltage $\left(V_{m}\right)$ and access resistance $\left(R_{s}\right)$ were monitored constantly. The acquisition of data was terminated when the $V_{m}$ was more positive than $-40 \mathrm{mV}$ or if the $R_{s}$ was $>20 \mathrm{M} \Omega$. In voltage-clamp recordings, the cell holding potential was $-77 \mathrm{mV}$ (corrected for junction potential), unless otherwise noted. For electrical stimulation, a glass patch pipette $(0.5-2 \mathrm{M} \Omega)$ was placed in the indicated regions of the bulb. For standard dynamic stimulation of ON afferents, brief pulses (100 $\mu \mathrm{s}$; 0.05-0.5 mA) triggered by a biphasic stimulus isolation unit (BSI-950; Dagan, Minneapolis, MN) were applied as a pattern consisting of five shorts bursts (three pulses at $100 \mathrm{~Hz}$ ) separated by $250 \mathrm{~ms}(4 \mathrm{~Hz})$. Each stimulus pattern was applied every $10-15 \mathrm{~s}$. When stimuli were applied to the external plexiform layer (EPL), mitral cell layer, and GCL, single pulses were used, each separated by $5 \mathrm{~s}$.

In most experiments, the test drugs were bath applied. In some studies testing the mechanisms of type 1 and type 2 synaptic events (see Fig. $2 c$ ), glutamate receptor antagonists [2,3-dihydroxy-6-nitro-7-sulfamoylbenzo-f-quinoxaline (NBQX) and DL-2-amino-5-phosphonopentanoic acid (DL-AP-5)] were applied focally in the GCL using a "puffer" pipette ( $3 \mu \mathrm{m}$ tip, Picospritzer; General Valve, Fairfield, NJ). Antagonist application was begun $1 \mathrm{~s}$ before the start of $\mathrm{ON}$ stimulation and persisted for $1-2$ s. In experiments in which NBQX eliminated type 2 events, I confirmed that NBQX application was confined to the GCL and did not affect ON-to-mitral cell transmission, based on the fact that NBQX did not reduce type 1 events, at least during the first two to three puffs. Repeated NBQX application eventually led to elimination of both type 1 and type 2 synaptic events, as NBQX diffused slowly into the EPL and glomerular layer.

Data analysis. For the analysis of type 1 and type 2 synaptic events during granule cell recordings, a standard event-detection algorithm was performed using Axograph software. In general, events were detected using templates and statistical criteria (variable between cells) designed to detect as many synaptic events as possible; results of the automated event-detection analysis were verified by visually inspecting a subset of the data traces. Estimates of the relative fraction of type 1 and type 2 events (see Fig. 1d) were obtained using detection templates with kinetics that matched the average EPSC seen in cells with only type 1 or type 2 events; stricter statistical criteria were used in this analysis.

In mitral cell recordings (see Fig. 4), estimates of the normalized IPSC frequency were obtained by analyzing the current traces in $40 \mathrm{~ms}$ increments. The computed IPSC frequencies were then plotted as a function of the average $I_{\text {slow }}$ current seen during the $40 \mathrm{~ms}$ segment. This analysis assumed that most of the IPSCs recorded in mitral cells reflected GABAergic inputs from granule cells rather than bulb periglomerular (PG) cells. This was reasonable, based on the fact that sectioning mitral cell primary dendrites (thereby removing inputs from PG cells) (Schoppa, 2006) has a negligible effect on IPSC frequency. IPSC frequencies in cells with and without primary dendrites, respectively, were $53 \pm$ $4 \mathrm{~Hz}(n=36)$ and $52 \pm 6 \mathrm{~Hz}(n=8)$.

In voltage-clamp recordings in granule cell pairs (see Fig. 6), analysis of EPSC synchrony was done by running an event-detection algorithm on one cell and examining the timing of EPSCs seen in the other cell. The EPSC time was taken from the time to $50 \%$ of peak current during the rising phase of the EPSCs. Values of $P$ (co-occurrence) for a given synchronization "window" were taken to be the conditional probability that, given an EPSC was observed in one cell at time $=t$, an EPSC was observed in the other cell in the interval between $t$ - window and $t+$ window.

For analyzing granule cell spike synchrony (see Fig. 7), spikes were detected in the two cells using a threshold analysis based on the peak spike amplitude (variable between granule cells). The four granule cell pairs chosen for the analysis had peaks in the spike-lag distributions near lag $=0$ that were deemed to be significant. Specifically, these were pairs in which the number of events in the histogram bins corresponding to |spike lag $\mid<5 \mathrm{~ms}$ deviated from the number of events in bins corresponding to $\mid$ spike lag $\mid$ between 10 and $15 \mathrm{~ms}$ by $>2$ SDs of the event values for bins corresponding to |spike lag $\mid$ between 10 and $25 \mathrm{~ms}$.

In mitral/granule cell-pair recordings (see Fig. 8), selection of pairs for analysis of the temporal relationship between granule cell spiking and mitral cell IPSCs was done based on the cross-correlograms computed from voltage-clamp recordings of granule and mitral cell synaptic activity. The four selected pairs had current cross-correlogram peak values $\geq 0.07$.

Statistical significance $\left({ }^{* *} p<0.05\right)$ was determined using the Student's $t$ test. Data values are reported as mean \pm SE.

\section{Results}

Experiments on granule cells were performed using $4 \mathrm{~Hz}$ patterned electrical stimulation of $\mathrm{ON}$ afferents (Fig. 1a), mimicking the breathing cycle in rats (Youngentob et al., 1987). Previous studies (Carlson et al., 2000; Schoppa and Westbrook, 2001) have established that $\mathrm{ON}$ stimulation causes concerted activation of mitral cells affiliated with single glomeruli, indicating effective stimulation of large groups of mitral cells ( $\sim 25$ mitral cells per glomerulus in rat). In addition, patterned stimuli (Schoppa and Westbrook, 2001; Schoppa, 2006) reproduce both odor-evoked slow phasic depolarizations in mitral cells (Margrie and Schaefer, 2003) and gamma frequency synchronized oscillatory activity (Adrian, 1950; Freeman, 1972; Kashiwadani et al., 1999).

\section{Two classes of glutamatergic excitatory events evoked by dynamic stimuli}

The first objective was to use voltage-clamp recordings from single granule cells (holding potential, $V_{\text {hold }}=-77 \mathrm{mV}$ ) to characterize the classes of synaptic inputs received by granule cells during patterned $\mathrm{ON}$ stimulation. In all experiments, granule cells displayed barrages of inward current events that persisted for the duration of the stimulus (Fig. 1). The exact kinetic characteristics of the events varied significantly between cells, in what appeared to be an age-dependent manner. In young animals [postnatal day 8 (P8) or younger], the events tended to have "moderate" decay kinetics (Fig. $1 a-c, \mathrm{GC} 1$ ) with a $20-80 \%$ rise time of $1.43 \pm 0.02$ $\mathrm{ms}$ and decay time constants of $5.7 \pm 0.3 \mathrm{~ms}(n=17)$. Approx- 
imately $44 \%$ of the granule cells ( 8 of 18 ) in young animals consisted entirely of such events (termed "type 1" events). In contrast, granule cells in bulb slices taken from older animals (older than P14) generally showed more rapid events (Fig. $1 a-c$, GC2) $(20-80 \%$ rise time, $0.34 \pm 0.01 \mathrm{~ms}$; decay time constant, $1.5 \pm 0.1 \mathrm{~ms} ; n=24)$, with $23 \%$ (7 of 30 ) of all cells from older animals consisting entirely of such events ("type 2" events). Most cells at all ages showed a mixture of type 1 and type 2 events (Fig. $1 a-c, \mathrm{GC} 3$ ) but a clear agedependent pattern could be seen when type 1 and type 2 events were counted across a large number of recordings (see Materials and Methods) (Fig. 1d). The fraction of total events that were in the fast type 2 class increased from $0.29 \pm 0.08$ $(n=18)$ at $\mathrm{P} 6-\mathrm{P} 8$ to $0.72 \pm 0.07(n=26)$ at P14-P17 $(p<0.001)$. A similar trend could be seen when comparing recordings from animals at $\mathrm{P} 6-\mathrm{P} 8$ versus $\mathrm{P} 21-\mathrm{P} 22$ $(n=4 ; p<0.01)$. These results indicate that the kinetic characteristics of synaptic events in bulb granule cells vary with age, with the majority of events in older rats being on a fast single-millisecond time scale.

Because patterned $\mathrm{ON}$ stimulation causes potent activation of mitral cells, the identified inward synaptic events in granule cells could reflect glutamatergic EPSCs evoked secondarily to mitral cell activation. Analyzing the synaptic events directly with glutamate receptor blockers was complicated by the fact that such blockers inhibited ON-to-mitral cell transmission. Application of a single stimulus (100 $\mu \mathrm{s}$; $0.1-0.5 \mathrm{~mA}$ ) in deeper regions of the bulb (Fig. 2a $a_{1}$ ), bypassing ON-to-mitral cell transmission, however, could effectively evoke single synaptic events that resembled the type 1 and type 2 events evoked by patterned ON stimulation, based on their similar kinetics $\left(\tau_{\text {decay }}, 7.9 \pm 0.9 \mathrm{~ms}, n=\right.$ 15 and $\tau_{\text {decay }}, 1.8 \pm 0.1 \mathrm{~ms}, n=8$, respectively, for the two classes) and sensitivity to glutamate receptor modulators [see experiments with cyclothiazide (CTZ) below]. The main components of the presumed type 1 and type 2 events were unaffected by the NMDA receptor antagonist DL-AP-5 ( $100 \mu \mathrm{M} ; n=5$ and 3 for type 1 and type 2 events, respectively) but were blocked by the AMPA/kainate receptor antagonist NBQX $(20 \mu \mathrm{M}$; percentage of peak amplitude reduction: $83 \pm 4 \%, n=6$ and $85 \pm$ $4 \%, n=4$ for type 1 and type 2 events, respectively) (Fig. $2 a_{2}$ ). The finding that type 1 and type 2 events evoked by ON stimulation were mediated by AMPA/kainate receptors was further confirmed by
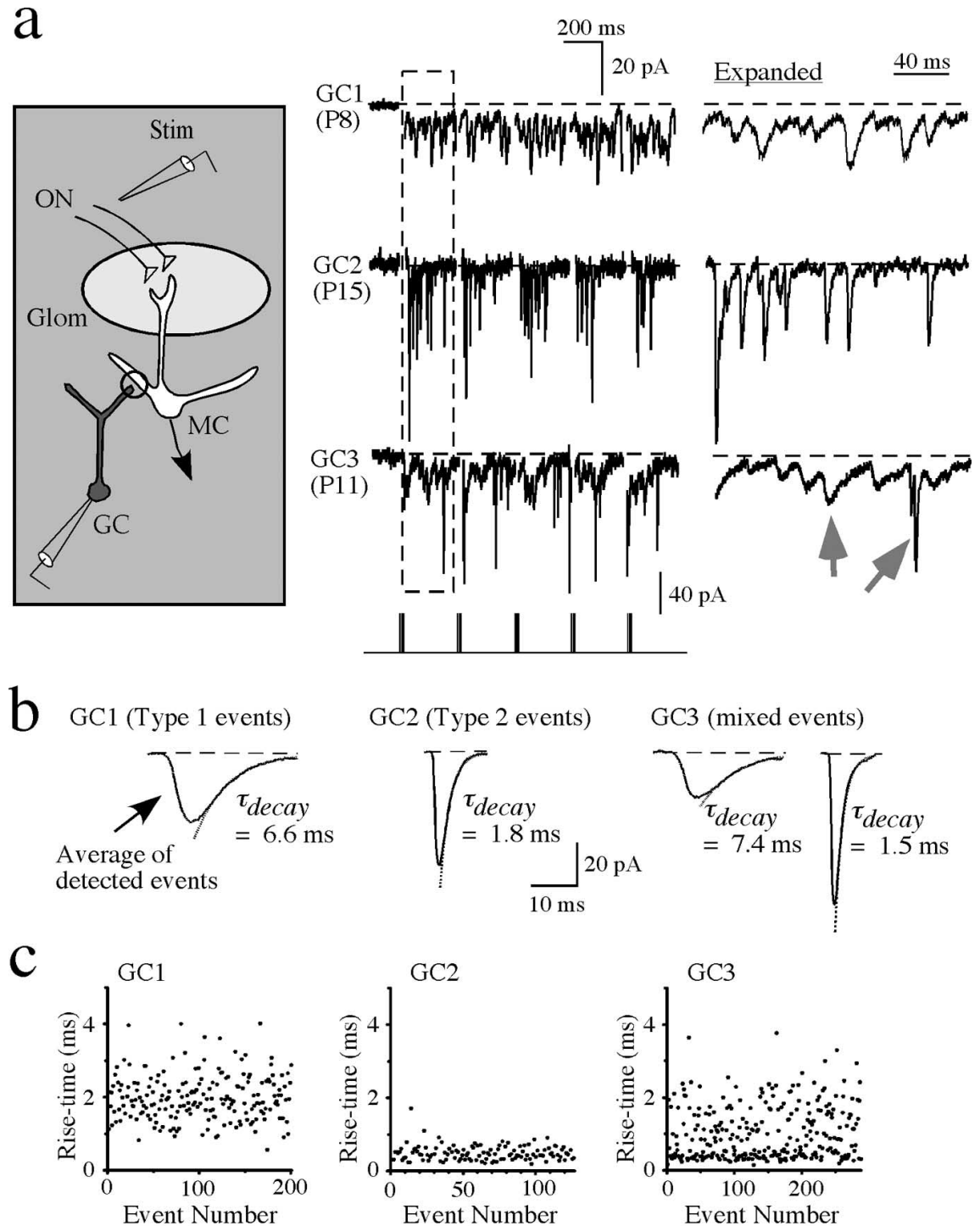

GC3 (mixed events)

d
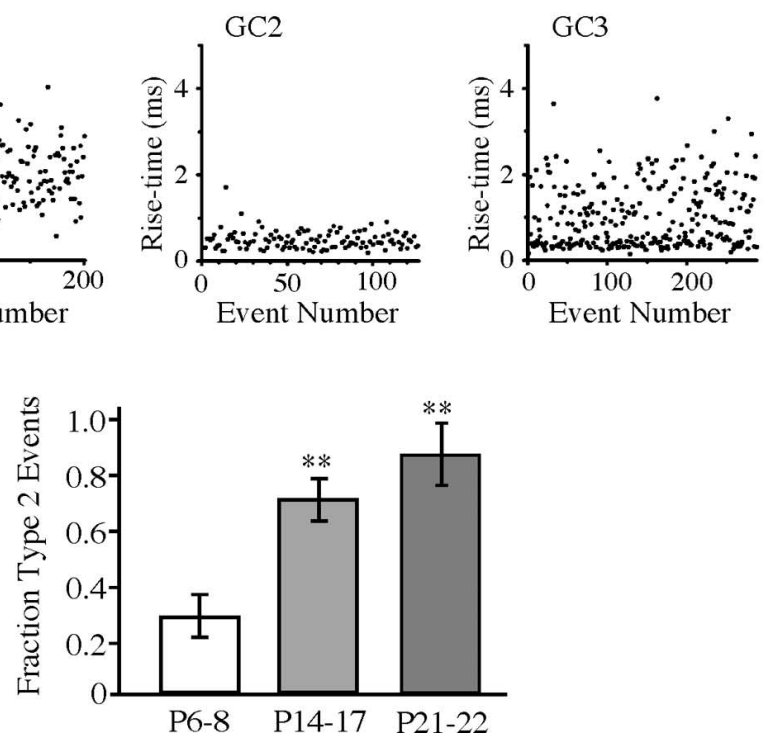

Figure 1. Two kinetic classes of synaptic events in granule cells evoked by dynamic stimulation. $\boldsymbol{a}$, Voltage-clamp recordings $\left(V_{\text {hold }}=-77 \mathrm{mV}\right)$ in three different granule cells in response to a $4 \mathrm{~Hz}$ patterned stimulation of $0 \mathrm{~N}$ afferents (stimulus pattern is shown at the bottom). The top granule cell (GC1), from a rat at P8, showed events that lasted $\sim 10 \mathrm{~ms}$. The kinetic profile of these type 1 events can be best seen in the expanded trace (right). GC2, from an older rat at P15, showed much faster events lasting only a few milliseconds (type 2 events). GC3, from a rat at P11, showed both type 1 and type 2 events (arrows on expanded trace). Left, The diagram illustrates some basic elements of the bulb circuit, including axodendritic connections between $0 \mathrm{~N}$ fibers and mitral cells (MC) in a glomerulus (Glom) and dendrodendritic connections (circle) between granule cells and mitral cells. Mitral cell axons (process with arrowhead) have collaterals (not shown) that extend into the GCL. Stim, Stimulation. $\boldsymbol{b}$, Averaged synaptic events detected from the three cells in $a$ using a standard event-detection algorithm (see Materials and Methods). The event detection for GC1 and GC2 was done using loose statistical criteria, in an attempt to find as many synaptic events as possible. The two average traces for GC3 reflect event detection done using stricter criteria to discriminate type 1 and type 2 events. c, Plots of the $20-80 \%$ rise times for the cells in $\boldsymbol{a}$. Note that the plot for $\mathrm{GC} 3$, with mixed events, shows events with fast rise times clustered at $\sim 0.4 \mathrm{~ms}$, as well as slower events. All event detection in this analysis was done using loose statistical criteria. $\boldsymbol{d}$, Fractional contribution of fast type 2 events relative to the total number of events for three different age groups. The values at both P14-P17 and P21-P22 were significantly larger than at P6-P8 (double asterisks). 

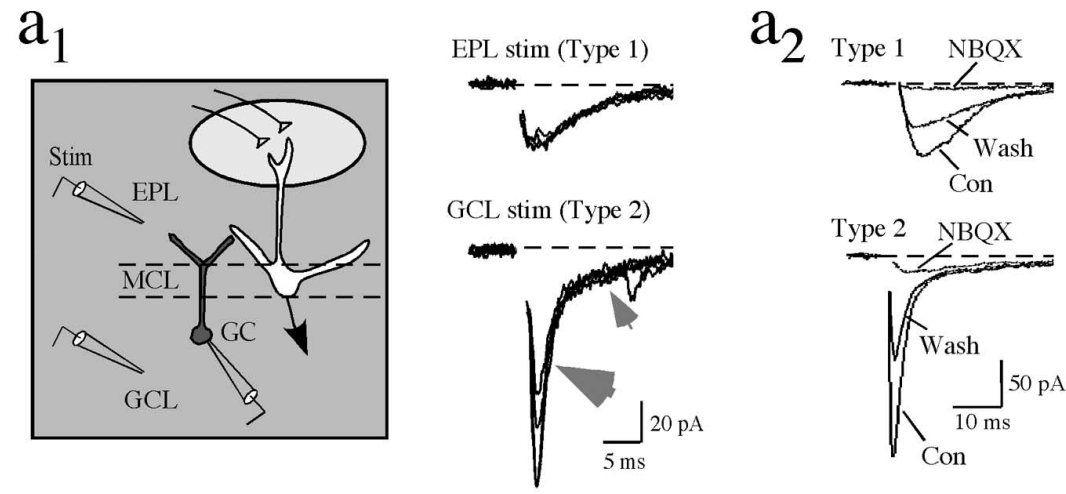

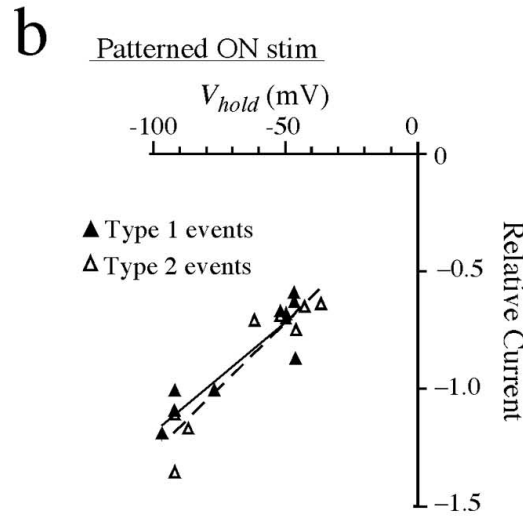

d

Patterned ON stim
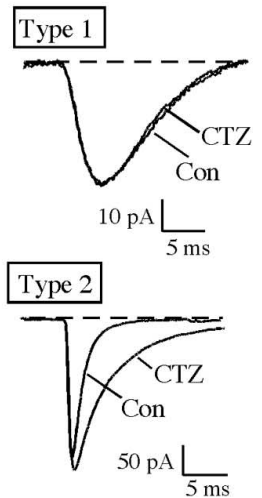
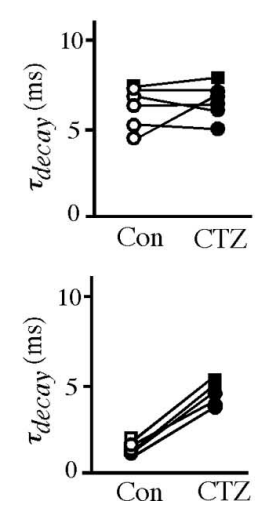

C Patterned ON stim

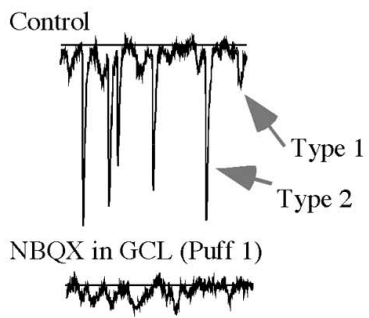

NBQX in GCL (Puff 5)

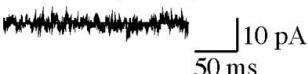

e

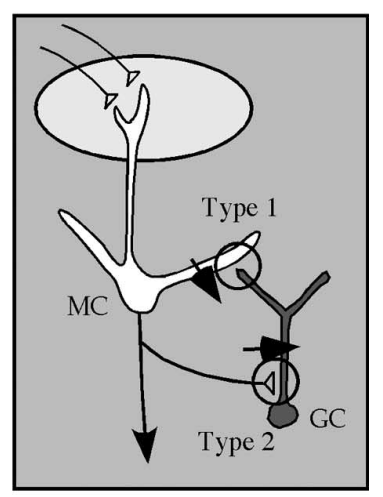

Figure 2. Mechanisms of synaptic events in granule cells. $\boldsymbol{a}_{1}$, Type 1 and type 2 events could be isolated using focal stimulation in more inner bulb layers, either in the EPL or the GCL. Stimulation in the EPL (4 superimposed example traces at top) evoked synaptic events that were kinetically similar to type 1 events evoked by patterned $0 \mathrm{~N}$ stimulation, whereas stimulation in the $\mathrm{GCL}$ (bottom traces) evoked responses that included a fast type 2-like component (large arrow). The latter response also showed a small, distinct slow component $\left(\tau_{\text {decay }}=16 \mathrm{~ms}\right.$ ) presumed to be mediated by NMDA receptors (small arrow). All events were recorded in the same granule cell from a rat at P10. MCL, Mitral cell layer. $\boldsymbol{a}_{2}$, Type 1 and type 2 events evoked by focal stimulation were reversibly blocked by the AMPA/kainate receptor antagonist NBQX (20 $\mu \mathrm{m})$. Each trace reflects an average of $\geq 11$ responses. $\boldsymbol{b}$, Voltage dependence of the average detected synaptic event evoked by patterned ON stimulation, taken from pairs showing mainly type 1 or type 2 events. The plotted current values, obtained from several cells, were normalized to the current at $-77 \mathrm{mV}$ in each cell (assigned -1.0). Note that currents were inward up to $-37 \mathrm{mV}$ and displayed an approximately linear dependence with voltage, consistent with a glutamatergic mechanism involving AMPA/kainate receptors. High current-noise levels prevented reliable measurements of current amplitudes at voltages greater than $-37 \mathrm{mV}$. c, Focal application of NBQX (20 $\mu \mathrm{m}$ ) in the $\mathrm{GCL}$ with a puffer pipette eliminated selectively fast type 2 events evoked by $0 \mathrm{~N}$ stimulation, further confirming involvement of AMPA/kainate receptors. In this experiment, repeated application of NBQX (bottom trace) eventually blocked all events, as NBQX diffused slowly into the EPL and glomerular layers. $\boldsymbol{d}$, Type 1 and type 2 events were differentially sensitive to CTZ $(50-100 \mu \mathrm{M})$. Data traces on the left reflect averaged detected events $(n \geq 52)$ taken from responses to patterned ON stimulation in two cells that showed only type 1 (top) or only type 2 (bottom) events. Summary plots on the right reflect decay time constants of responses to $0 \mathrm{~N}$ stimulation (circles) or, in a few cases, focal stimulation in more inner layers (squares). e, Proposed mechanisms for EPSCs. Type 1 events reflect dendrodendritic synaptic inputs from mitral cell (MC) secondary dendrites in the EPL, whereas type 2 events reflect inputs from mitral cell axon collaterals in the GCL. Stim, Stimulation; Con, control. the shape of the voltage dependence of the current events (Fig. 2b), specifically their approximately linear dependence with voltage and the fact that the events were inward-going at voltages up to $-37 \mathrm{mV}$. Also, the type 2 events evoked by ON stimulation could be eliminated when NBQX $(20 \mu \mathrm{M} ; n=4)$, but not DL-AP-5 (100 $\mu \mathrm{M}$; $n=2$ ), was applied focally via a puffer pipette in the GCL (Fig. 2c) (see Materials and Methods).

I next attempted to distinguish the type 1 and type 2 EPSCs pharmacologically using CTZ (50-100 $\mu \mathrm{M})$, which is a drug that can distinguish between different subtypes of AMPA and kainate receptors. For these experiments, I combined analyses of events evoked by focal stimulation in inner bulb layers and events evoked by patterned ON stimulation (Fig. 2d), for the latter choosing granule cells that showed only type 1 or type 2 synaptic events to avoid ambiguities in interpreting CTZ effects on synaptic kinetics. CTZ had no effect on type 1 events $(9 \pm 10 \%$ increase in decay time constant; $n=6$ ) but lengthened the decay time constant of type 2 events (by $218 \pm 35 \% ; n=5 ; p<0.05)$. These results indicate that type 1 events are mediated by CTZ-insensitive kainate receptors, or possibly AMPA receptors composed of CTZinsensitive subunits (Koike-Tani et al., 2005), whereas type 2 events are mediated by CTZ-sensitive AMPA receptors. Type 1 and type 2 events appeared to differ in one other important respect. In experiments using focal stimulation in deeper bulb layers (Fig. 2a), there was a strong stimulus location dependence on the class of events evoked. Type 1 events ( $\tau_{\text {decay }} \geq 4 \mathrm{~ms}$ ) were nearly always evoked by stimulation in the mitral cell or EPLs (in 18 out of 20 cells), whereas type 2 events $\left(\tau_{\text {decay }} \leq 2.5 \mathrm{~ms}\right)$ were evoked by stimulation in the GCL (in 11 of 13 cells). These results suggest that type 1 and type 2 events have different locations on granule cells (Fig. 2e), with type 1 events likely reflecting inputs on distal portions of granule cell apical dendrites (which extend through the mitral cell and EPLs) and type 2 inputs being in the GCL (either on proximal portions of apical dendrites, as shown in Fig. 2e, or on basal dendrites). The differential localization of the events was also confirmed by the puffer experiments described above (Fig. 2c), in which NBQX application in the GCL caused selective block of type 2 events without affecting type 1 inputs $(n=3)$.

Previous studies examining spontaneous responses or responses to single-pulse stimuli have shown that granule cells can display $\mathrm{GABA}_{\mathrm{A}}$ (Carleton et al., 2003; 
Pressler and Strowbridge, 2006) or NMDA (Isaacson and Strowbridge, 1998; Schoppa et al., 1998) (Fig. $2 a_{1}$, slow component of response to GCL stimulation) receptormediated synaptic currents, in addition to AMPA/kainate receptor-mediated EPSCs. $\mathrm{GABA}_{\mathrm{A}}$ receptors, however, did not contribute significantly to responses during patterned $\mathrm{ON}$ stimulation. In the analysis of the voltage dependence of the synaptic current events (Fig. 2b), the "average" event failed to reverse polarity around the chloride equilibrium potential $(-77 \mathrm{mV})$, as would be expected if $\mathrm{GABA}_{\mathrm{A}}$ receptors mediated a significant fraction of the events. Also, in experiments in which the standard low-chloride-containing patch pipette solution was replaced with high chloride $(115 \mathrm{~mm})$ to augment possible GABAergic events $\left(V_{\text {hold }}=-77 \mathrm{mV}\right.$ ), only 2 of 12 granule cells showed current events sensitive to the $\mathrm{GABA}_{\mathrm{A}}$ receptor blocker bicuculline methiodide (BMI; 10 $\mu \mathrm{M})$. As for NMDA receptors, it was difficult to quantify their contribution during patterned $\mathrm{ON}$ stimulation, although it was likely that they mediated a component of the granule cell current response. A slowly decaying NMDA receptor-mediated current could not be detected readily in the isolated transient synaptic responses during $\mathrm{ON}$ stimulation (at a $V_{\text {hold }}$ of $-37 \mathrm{mV}$ or less) (Fig. 1 $a$, traces for GC2), but this absence most likely simply reflected high baseline noise rather than the loss of functioning NMDA receptors (because NMDA receptors are relatively immune to desensitization) (Jonas and Spruston, 1994).

\section{Properties of granule cell activation during dynamic stimulus conditions}

Current-clamp recordings from granule cells were next used to test how the synaptic inputs shape granule cell activation during patterned ON stimulation. Granule cell responses (Fig. $3 a$ ) consisted of barrages of EPSPs along with spikes overriding some of the EPSPs. On average, granule cells spiked at frequencies between 5 and $10 \mathrm{~Hz}$ and showed specific spike-pattern tendencies that have been observed in vivo (Cang and Isaacson, 2003), for example, adaptation (spike rate, $10.9 \pm 1.3 \mathrm{~Hz}$ after the first stimulus burst vs $4.3 \pm 0.4 \mathrm{~Hz}$ at later times; $n=23 ; p<0.01$ ) and stimulus coupling (spike rate, $9.6 \pm 0.7 \mathrm{~Hz}$ during the first $150 \mathrm{~ms}$ after each stimulus burst vs $4.0 \pm 1.3 \mathrm{~Hz}$ during the last $75 \mathrm{~ms}$; $n=5 ; p<0.05)$. Close examination of the timing of individual spikes indicated that granule cells spiked very shortly after the beginning of each EPSP (Fig. 3a, expanded examples, Fig. 3b, cumulative histogram) and also generally only spiked once for each EPSP. Across the population of test granule cells, short spike delays were seen in all cells (Fig. 3c), with the delay being shortest in cells showing the highest proportion of fast type 2 EPSCs in voltage clamp $(p<0.0002)$. The modest (although highly significant) dependence of the spike delay on synaptic kinetics helped confirm that the upward voltage deflections that led to fast spiking in granule cells were indeed EPSPs, rather than fluctuations in granule cell voltage caused by intrinsic conductances. This conclusion was also supported by studies done in granule cell pairs showing synchronized synaptic events (Fig. 3d) (see below, Mechanisms to synchronize granule cell pairs), in which the subthreshold fluctuations that preceded spiking in one granule cell could be aligned to clear EPSPs in the other cell. Together, these results indicate that granule cells respond to their glutamatergic synaptic inputs during dynamic stimulus conditions with very short spike delays, being typically $\leq 10 \mathrm{~ms}$ in cells from older animals displaying mainly type 2 synaptic events (Fig. $3 c$ ).

The fast spiking in granule cells during dynamic stimulation contrasts with static, single-pulse stimulus conditions, when granule cells display delayed spiking that depends on kinetically slow NMDA receptors (Schoppa et al., 1998) (see Fig. 7a). I thus wondered whether granule cell activation under dynamic conditions is fundamentally different from static conditions, being dependent on fast AMPA/kainate receptors on granule cells. Testing which glutamate receptor drives granule cell activation during dynamic stimulation directly with glutamate receptor antagonists was, as above, complicated by the sensitivity of mitral cell activation to these blockers. This problem was circumvented here by taking advantage of the fact that robust mitral cell responses to ON stimulation can persist even when NMDA receptors are blocked if network inhibition is partially reduced with a 


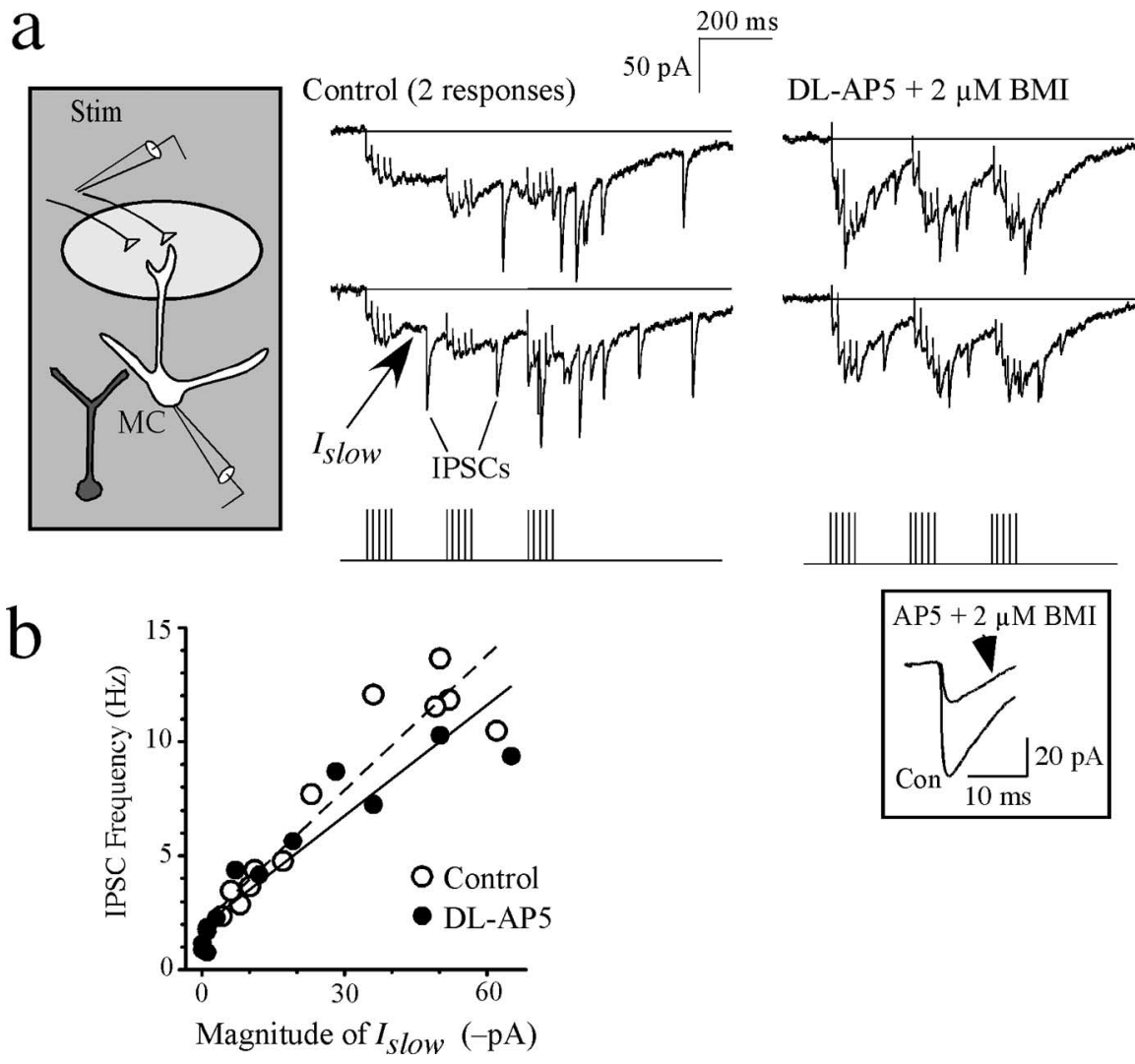

Figure 4. Granule cell activation during dynamic ON stimulation does not depend on NMDA receptors. $\boldsymbol{a}$, The glutamate receptor dependence of granule cell activation was assessed by measuring the frequency of IPSC in single voltage-clamped mitral cells (MC). Two examples each are shown of records obtained under control conditions (left traces) and when NMDA receptors were blocked with DL-AP-5 (100 $\mu \mathrm{m}$; right traces). Note that responses under both conditions included a slow inward current component $\left(I_{\text {slow }}\right)$, which reflected mitral cell activation, as well as barrages of rapid IPSCs sensitive to the GABA receptor blocker BMI (boxed inset at bottom right). A concentration of $2 \mu \mathrm{M} B M I$ (about a half-maximal dose) was included in the solution containing DL-AP-5 to reduce network inhibition and offset effects of NMDA receptor blockade on mitral cell activation. In these experiments, the K-gluconate in the pipette was replaced with $\mathrm{KCl}$ to augment inward $\mathrm{GABA}_{\mathrm{A}}$ receptor-mediated currents. Con, Control. $\boldsymbol{b}$, Relationship between the magnitude of $I_{\text {slow }}(x$-axis) and IPSC frequency ( $y$-axis) for the experiment in $\boldsymbol{a}$. The nearly superimposable plots under control conditions and in DL-AP-5 indicate that blockade of NMDA had little effect on IPSC frequency, when normalized to mitral cell activation. Dashed and solid lines reflect fits of control and DL-AP-5 data.

submaximal concentration of BMI ( $2 \mu \mathrm{M})$ (Schoppa and Westbrook, 2001). I also used the frequency of IPSCs in mitral cells as a reporter of granule cell activation, rather than recordings of granule cell activity itself (see Materials and Methods) (Fig. 4a). Importantly, this strategy allowed normalization of granule cell activation to the degree of mitral cell activation, which could be estimated from the slow inward current $\left(I_{\text {slow }}\right)$ that underlied the IPSCs. $I_{\text {slow }}$ drives the previously characterized synchronized depolarizations within glomerulus-specific mitral cells (Carlson et al., 2000; Schoppa and Westbrook, 2001), and thus its magnitude provided a reasonable estimate of activation in the network with which the test mitral cell was affiliated. Analysis of the normalized IPSC frequency (Fig. $4 b$ ) showed that blockade of NMDA receptors with DL-AP-5 (100 $\mu \mathrm{M})$, in fact, had little effect (25 $\pm 12 \%$ increase in slope of lines fitted to plots relating IPSC frequency to $I_{\text {slow }}$ amplitude; $n=5 ; p=0.21$ ). The lack of effect of DL-AP-5 on IPSC frequency was likely not an artifact of the smaller IPSCs in DL-AP-5 plus submaximal BMI (because, if anything, an IPSC-detection artifact would have led to reduced IPSC frequency counts) and instead is best explained if granule cell activation during dynamic stimulation depends mainly on AMPA/kainate receptors.

One clue into why granule cell activation properties could differ so much between static versus dynamic stimulus condi- tions was provided by a previous study that showed that the NMDA receptor dependence of granule cell activation under static conditions is because of the action of A-type potassium $\left(I_{\mathrm{A}}\right)$ channels on granule cells (Schoppa and Westbrook, 1999). These channels can selectively attenuate the fast AMPA/kainate receptor-mediated component of the EPSP, with little effect on the NMDA receptor-mediated depolarization. During patterned ON stimulation, granule cells generally underwent sustained depolarizations to $-50 \mathrm{mV}$ or greater, in which $>90 \%$ of $I_{\mathrm{A}}$ channels should be silenced by inactivation (Schoppa and Westbrook, 1999) and therefore unavailable to attenuate AMPA/ kainate receptor-mediated inputs. To test the degree of $I_{\mathrm{A}}$ inactivation directly, current-clamp recordings in granule cells were done in which short current injections (2 ms; 80-350 pA) were applied to measure the availability of $I_{\mathrm{A}}$ channels (Fig. 5a). The $I_{\mathrm{A}}$-mediated component of the voltage response was determined by application of the $I_{\mathrm{A}}$ blocker 4-aminopyridine (4-AP; $10 \mathrm{~mm}$ ) and calculation of the $I_{\mathrm{A}}$-mediated "difference potential" (Fig. $5 b$ ). Dynamic stimulation virtually eliminated this difference potential ( $90 \pm 17 \%$ decrease; $n=7 ; p<0.01)$. These results indicate that $I_{\mathrm{A}}$ channels, which produce slow, NMDA receptor-mediated granule cell activation during static conditions, are inactivated during dynamic stimulation.

\section{Mechanisms to synchronize granule cell pairs}

I next turned to recordings in granule cell pairs. A previous study (Schoppa, 2006) established that different granule cells can receive synchronized excitatory synaptic inputs, at least those that resemble the fast type 2 variety characterized here. However, the synchronized inputs have not been characterized quantitatively in pair recordings with respect to their timing, number, and input subtype. In addition, the relationship between the inputs and synchronized spiking in granule cells and GABA release has not been tested.

To examine the timing of the excitatory inputs, voltage-clamp recordings of EPSCs were performed in granule cell pairs while sorting pairs simultaneously by input type (Fig. $6 a$ ). Analysis of 23 such pair recordings revealed several patterns. The first was that EPSC synchrony between granule cells was remarkably precise. When measurements of "EPSC-lags" between granule cells were compiled into a histogram, the distributions were well fitted by Gaussian functions with SD $\sigma_{\text {EPSC-lag }}$ values averaging $<0.5$ $\mathrm{ms}(0.42 \pm 0.05 \mathrm{~ms} ; n=8)$. Second, there appeared to be no relationship between synchrony and whether the dominant inputs were type 1 or type 2 . This pattern was seen regardless of whether synchrony was quantified from measurements of EPSClags (Fig. $6 b)\left(p=0.21\right.$ for correlation between $\sigma_{\text {EPSC-lag }}$ and fraction of type 2 inputs; $n=8$ ) or from measurements of current cross-correlation ( $p=0.55$ for correlation between crosscorrelation peak and fraction of type 2 inputs; $n=23$ ). Syn- 
chrony could even be observed between type 1 and type 2 inputs in different granule cells (Fig. 6c). The third pattern is apparent in the plot in Figure $6 d$ that relates the fraction of EPSCs that were synchronized $[P($ co-occurrence $)]$ for different "synchronization" time windows. As expected, estimates of the synchronized fraction increased for larger windows, but the plot rises most steeply for increasing windows between 0.2 and $1.0 \mathrm{~ms}$, matching the shape of the EPSC-lag distributions (Fig. 6a). Using a window value of $1 \mathrm{~ms}$ as a cutoff for synchronization, approximately onehalf $(51 \pm 3 \% ; n=8)$ of the EPSCs were estimated to be synchronized. None of the 23 pairs analyzed displayed evidence for electrical coupling in current-clamp recordings, based on the absence of an effect of a hyperpolarizing current injection in one granule cell $(-10$ to $-40 \mathrm{pA}, 500 \mathrm{~ms})$ on the voltage response in the other cell. Thus, the synchronized EPSCs in granule cell pairs must reflect distinct but synchronized glutamatergic synaptic inputs coming from mitral cells.

From the point of view of the granule cell output, a large number of precisely synchronized excitatory inputs onto granule cells likely promotes synchronized spike activity, although it does not guarantee it. The key issue here is the variability, or "jitter," in the spike response time in single granule cells, which can act to desynchronize spiking even under conditions in which cells receive precisely synchronized inputs. This phenomenon is well illustrated by current-clamp recordings in granule cell pairs that were done under static stimulus conditions (Fig. $7 a_{1}$ ), in which different granule cells were forced to receive EPSPs at the same time by application of single stimuli in the GCL. Under these conditions, the delay to spiking after the beginning of the EPSP was long and highly variable between trials ( $\mathrm{SD} \sigma_{\mathrm{GC}}$ spike-delay, $16 \pm 3 \mathrm{~ms} ; n=8$ ) (Fig. $7 a_{1}$, boxed inset). At the same time, there were large differences in the exact time of spiking between the two cells. Distributions of between-granule cell "spike-lag" values were fitted with Gaussian functions with SD $\sigma_{\mathrm{GC}-\mathrm{GC} \text { spike-lag }}$ values that averaged $20 \pm 4 \mathrm{~ms}(n=4)$ (Fig. $\left.7 a_{2}\right)$. Granule cell spiking, however, behaved quite differently during dynamic ON stimulation (Fig. $7 b$ ), when granule cells showed spike delays with less jitter ( $\sigma_{\mathrm{GC}}$ spike-delay, $4.7 \pm 0.4 \mathrm{~ms} ; n=15$ ) (Fig. $3 a$, see superimposed family of isolated EPSPs) and more synchronized spiking $\left(\sigma_{\mathrm{GC}-\mathrm{GC} \text { spike-lag}}, 3.5 \pm 1.1 \mathrm{~ms} ; n=4\right)$. That the precision of spike synchrony during static versus dynamic stimulus conditions reflected variations in spike delays in single granule cells was supported by the close match between the $\sigma_{\mathrm{GC}-\mathrm{GC}}$ spike-lag and $\sigma_{\mathrm{GC} \text { spike-delay }}$ values across all experiments (Fig. $7 c$ ). These results suggest that the same biophysical mechanisms that produce fast, low-jitter spiking in single granule cells during dynamic stimulus conditions also ensure precisely synchronized spiking.

\section{Timing of the GABAergic output from granule cells}

Although the above analysis indicated that mechanisms exist that drive synchronized spiking in different granule cells, the inhibitory output from those cells need not be synchronized, if GABA release occurs that is not time-locked to spikes. Such asynchronous GABA release could arise, for example, from localized calcium signals associated directly with NMDA receptors on granule cell dendritic spines (Chen et al., 2000; Halabisky et al., 2000), or if there is prolonged transmitter release associated with calcium increases that follow an action potential (Barrett and Stevens, 1972). To assess the timing of the GABAergic output from granule cells directly, a last set of experiments was done in which granule cell spikes and mitral cell IPSCs were simultaneously recorded in granule/mitral cell pairs (Fig. 8a). In these experiments, the test granule and mitral cells were not connected di-
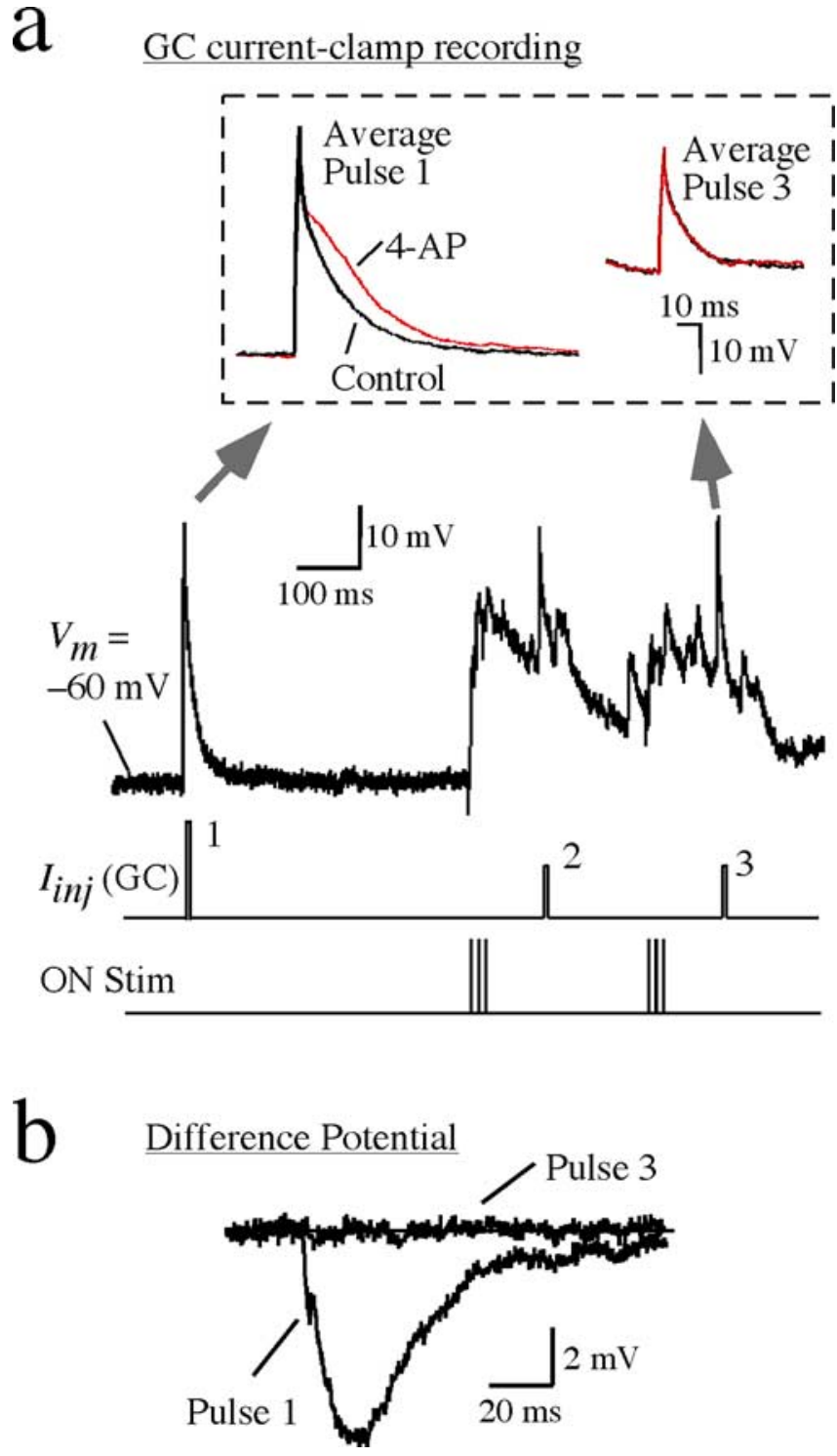

Figure 5. A-type potassium channels $\left(I_{A}\right)$ on granule cells are inactivated during dynamic stimulation. $\boldsymbol{a}$, Protocol used to assess whether the AMPA/kainate receptor dependence of granule cell $(\mathrm{GC}$ ) activation during dynamic ON stimulation (Stim) could be attributed to inactivation of $I_{A}$ channels on granule cells. Three "test" stimuli consisting of depolarizing current injections $\left(I_{\text {Inj }}=100-250 \mathrm{pA}\right)$ were applied to the granule cell, one before and two after the start of $0 \mathrm{~N}$ stimulation (see diagram traces at the bottom). The magnitude of current injection was reduced during $0 \mathrm{~N}$ stimulation to maintain similar peak granule cell depolarization. The boxed region at the top shows the averaged responses obtained under control conditions and in the presence of 4-AP for pulses 1 and 3 (average of $\geq 22$ responses). $\boldsymbol{b}$, The $I_{A}$-mediated difference potential, used to measure the availability of $I_{A}$ channels, computed from the traces in $a$ obtained under control conditions and in 4-AP.

rectly to each other (based on the absence of synaptic events in one cell evoked by direct stimulation of the other cell), yet the two cells were part of the same synchronized network of cells (Fig. $8 a$, diagram). Such an experimental configuration had an important practical advantage in that it allowed me to examine the output of a synchronized granule cell network without concern about calcium-buffering effects on GABA release.

If GABA release from granule cells can be supported by "slow" calcium signals, the prediction is that each granule cell spike should be associated with a relatively long-lasting barrage of IPSCs in the mitral cell. However, this was not observed. When mitral cell current was aligned to the spike in the granule cell, the 
a

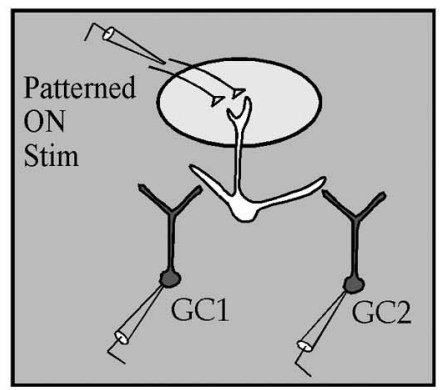

Pair 1

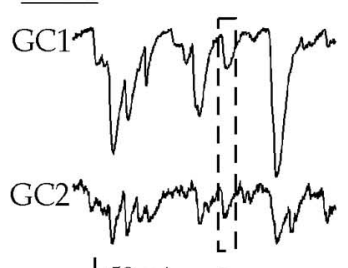

$\underset{50 \mathrm{~ms}}{50 \mathrm{pA}}$

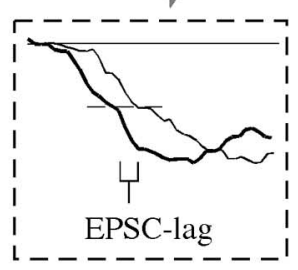

Pair 2

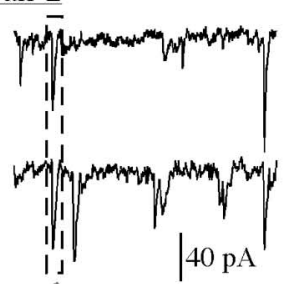

$1 \mathrm{~ms}$
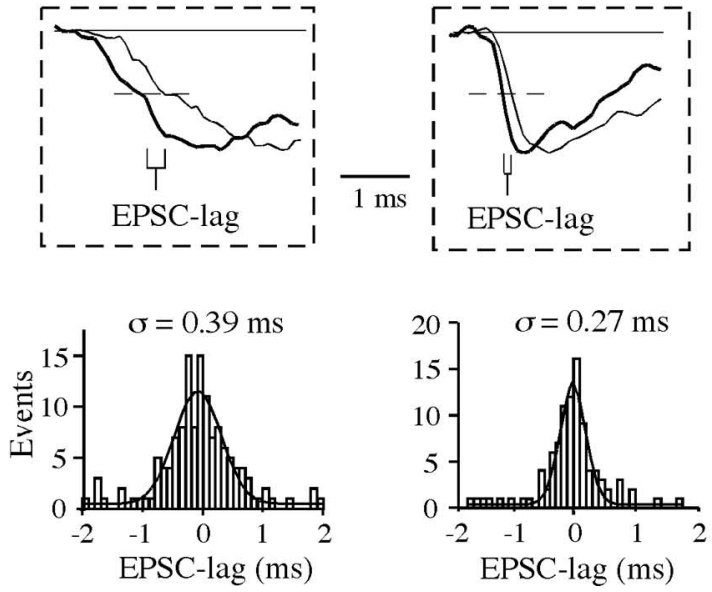

Figure 6. Granule cell (GC) pairs receive massive, precisely synchronized excitatory inputs from mitral cells during patterned ON stimulation. $\boldsymbol{a}$, EPSCS recorded in two granule cell pairs that displayed mainly either type 1 (Pair 1; left) or type 2 (Pair 2; right) events. The dashed boxes indicate instances in which the EPS(s were synchronized (enlarged in middle panels). The distributions of EPSC-lags between the two cells (bottom) show that EPSCs were synchronized on a time scale of $<1$ ms for both pairs. Distributions were fitted with Gaussian functions with the indicated $\sigma$ values. Stim, Stimulation. $\boldsymbol{b}$, Across eight granule cell-pair recordings, there was no correlation ( $p=0.21$ ) between the $\sigma$ values derived from Gaussian fits of the EPSC-lag distributions and the fraction of type 2 inputs. The eight pairs selected for this analysis were those that displayed the highest level of synchrony, based on current cross-correlation measurements. $c$, Type 1 and type 2 inputs could be synchronized in different granule cells. The trace for GC1, which had mainly fast type 2 inputs, reflects the average detected EPSC in that cell. The superimposed trace for GC2, which had mainly type 1 events, reflects the average current time-locked to the detected EPSCs in GC1. $\boldsymbol{d}$, The fraction of synchronized excitatory inputs in granule cells was computed from the probability that EPSCs c0-occurred [P(c0-occurrence)] for different time windows (see Materials and Methods). As expected, $P$ (co-occurrence) increases for larger windows, although it does so most steeply for windows between 0.2 and $1 \mathrm{~ms}$. A window value of $1 \mathrm{~ms}$ (vertical dashed line) was used as a cutoff to determine whether EPSCs were synchronized. Each data point reflects an average from the eight pairs described in $\boldsymbol{b}$.

spike-locked current $\left(I_{\text {lock }}\right)$ (Fig. $\left.8 b, c\right)$ was very short in duration, indeed so short that its duration $(7.2 \pm 1.9 \mathrm{~ms} ; n=4)$ was indistinguishable from the time course of the isolated unitary IPSC $(6.2 \pm 0.3 \mathrm{~ms} ; n=4)$. These results indicate that GABA release from a synchronized set of granule cells happens in a very narrow time window of a few milliseconds surrounding the time of granule cell spiking.

\section{Discussion}

Recent studies in olfactory bulb slices have identified several receptor and ion channel mechanisms that can impact the most common class of interneurons of the bulb, the granule cells, at least under static stimulus conditions. Here, using $4 \mathrm{~Hz}$ patterned stimulation of the ON, I performed the first detailed analysis of granule cells under dynamic conditions that approximate the physiological situation.

\section{Synaptic mechanisms in granule cells}

Voltage-clamp recordings in single granule cells showed that a large majority of the transient synaptic events evoked by patterned ON stimulation were glutamatergic EPSCs mediated by AMPA/kainate receptors, with little involvement of $\mathrm{GABA}_{\mathrm{A}} \mathrm{re}$ ceptors. The glutamatergic EPSCs, moreover, could be classified into two discrete groups on the basis of kinetics, receptor type, and anatomical location (Fig. 2e). The first of these (type 1) were $\sim 5-10 \mathrm{~ms}$ events that appear to originate on distal, apical dendrites at dendrodendritic synapses with mitral cells. Based on their sensitivity to NBQX but lack of effect of CTZ, these events appear to reflect activation of kainate receptors on granule cells (Montague and Greer, 1999) or possibly a CTZinsensitive subtype of AMPA receptor. The second class of events (type 2) were faster $\sim 1-2$ ms events mediated by CTZsensitive AMPA receptors located in the GCL, likely reflecting inputs from recurrent mitral cell axon collaterals (Shepherd et al., 2004). Although it cannot be excluded that type 2 events reflect centrifugal inputs from the olfactory cortex that also pass into the GCL, a mechanism involving mitral cell axon collaterals is much more consistent with the observations that type 2 events were activated by $\mathrm{ON}$ stimulation and also could be synchronized tightly to type 1 events reflecting mitral cell dendrodendritic inputs (Fig. 6c). Interestingly, the frequency of type 1 and type 2 events in these studies varied with age, with the fast AMPA receptor-mediated type 2 events becoming dominant in older rats (older than P14). This change could, at least in part, reflect progression of granule cell spine maturation from apical to basal dendrites (Matsutani and Yamamoto, 2004).

In addition to identifying the types of synaptic inputs that granule cells receive during dynamic stimulation, this study also examined how inputs shape granule cell activation. The main finding, that granule cell activation depends mainly on kinetically fast AMPA/kainate receptors, differs from previous studies, done under static conditions, that argued that granule cell activation requires NMDA receptors (Isaacson and Strowbridge, 1998; Schoppa et al., 1998). The AMPA/kainate receptor dependence of granule cell spiking observed here may be at least partly because of the fact that dynamic stimulation inactivates A-type potassium channels $\left(I_{\mathrm{A}}\right)$ in granule cells (Fig. 5) that, under static conditions, attenuate AMPA/kainate receptor-mediated inputs (Schoppa and West- 
brook, 1999). Such a mechanism would not only permit AMPA/kainate receptors to drive granule cell spiking but would also prevent action of NMDA receptors, because the early spike-associated afterhyperpolarization would counteract the slow NMDA receptor-mediated depolarization. Also, it appears that there is little, if any, spike-independent GABA release from granule cells driven by calcium signals associated directly with NMDA receptors (Chen et al., 2000; Halabisky et al., 2000). This conclusion was supported by both the lack of effect of AP-5 on mitral cells IPSCs (Fig. 4), as well as the precise temporal coordination between granule cell spikes and IPSCs (Fig. 8).

Although these studies of synaptic mechanisms in granule cells were done in vitro, the results likely have bearing for the natural situation. Previous work done in mitral cells (Schoppa and Westbrook, 2001; Schoppa, 2006), together with the present experiments in granule cells, show that patterned electrical stimuli can reproduce basic oscillatory and temporal features of odor-evoked responses (Adrian, 1950; Kashiwadani et al., 1999; Cang and Isaacson, 2003; Margrie and Schaefer, 2003). Additional experiments will be required to address specific unresolved issues related to granule cell mechanisms relevant to the natural situation (e.g., the possible impact of different frequencies/ strength of afferent stimulation or modulation by centrifugal inputs).

\section{Mechanisms of gamma frequency synchronized oscillations}

At a network level, granule cells are involved in the generation of gamma frequency synchronized oscillatory activity in the bulb, through their back-and-forth synaptic interplay with mitral cells (Rall and Shepherd, 1968; Friedman and Strowbridge, 2003; Lagier et al., 2004). Recent studies in mitral cell pairs (Galan et al., 2006; Schoppa, 2006) revealed some aspects of how granule cells impact mitral cells through GABAergic inputs. Specifically, mitral cells spike in synchrony as they recover from IPSPs imposed by granule cells. The present studies examined the other side of this exchange: how mitral cells synchronize granule cells through glutamatergic inputs. Recordings in granule cell pairs showed that mitral cells provide a massive number of synchronized excitatory inputs, and the resulting EPSPs are effective in synchronizing granule cell spiking because different granule cells show uniform spike-response times to the EPSPs. A key factor in determining the precision of granule cell synchrony is the speed of the underlying transmitter receptors. Kinetically, fast AMPA/ kainate receptors that predominate during dynamic stimulus Stimulation.
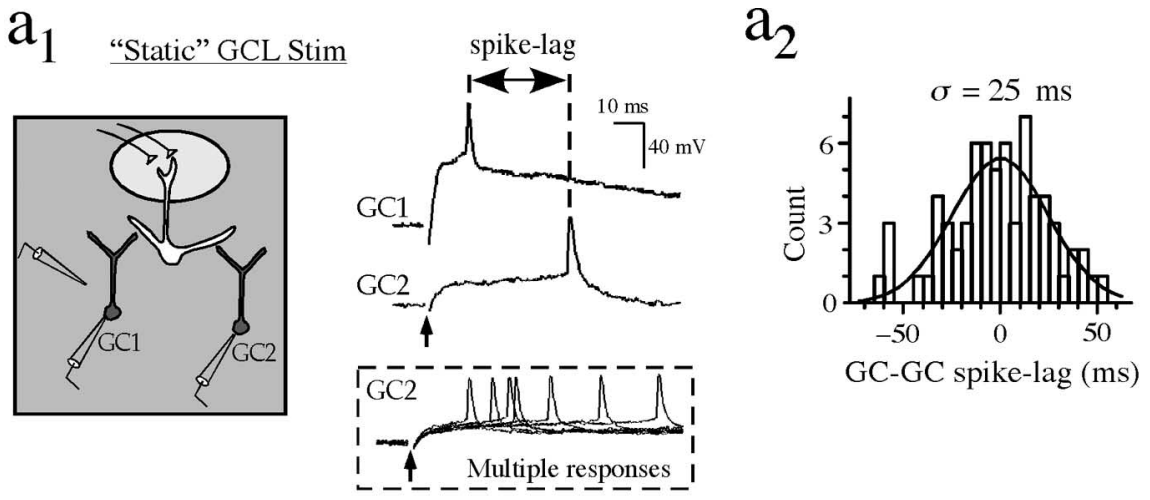

$\mathrm{b}_{1}$ patterned ON Stim
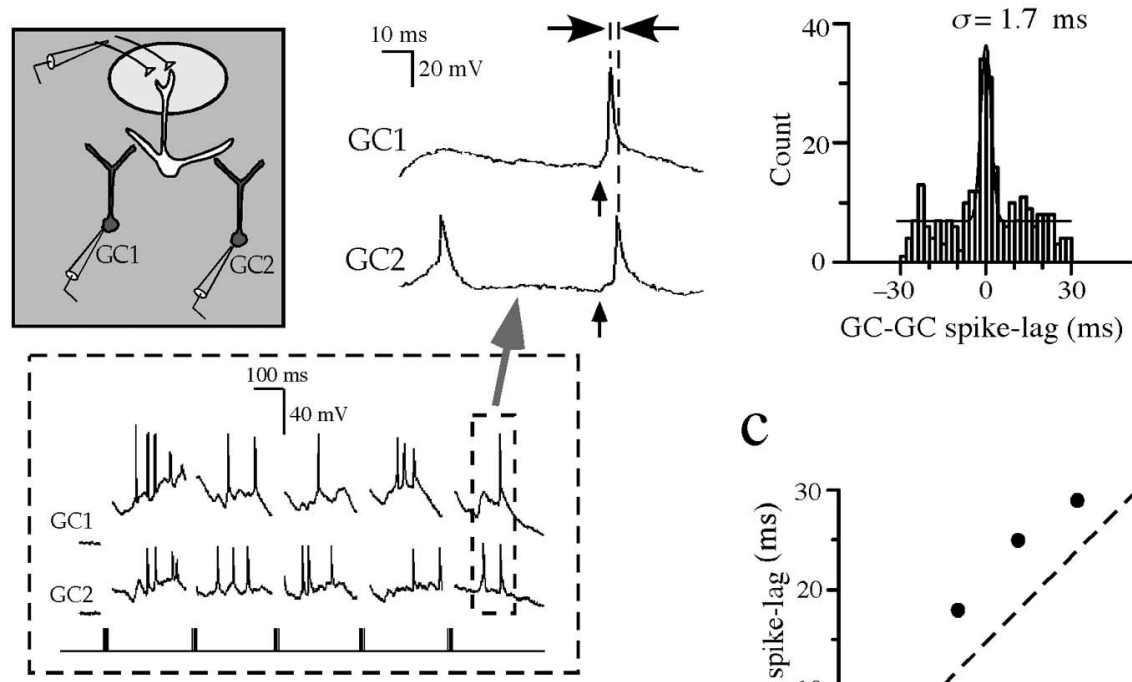

C

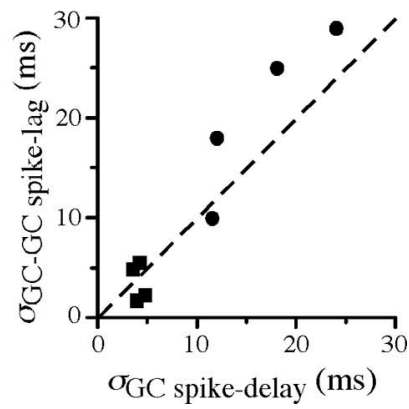

Figure 7. Relationship between single-cell activation kinetics and the precision of synchronized spiking in granule cell (GC) pairs. $\boldsymbol{a}_{1}$, Current-clamp responses in a granule cell pair under static stimulus conditions [i.e., after focal stimulation in the GCL (1 pulse, $100 \mu \mathrm{s})$ ]. In this example, both GC1 and GC2 displayed delayed spiking, the time of which also varied significantly from trial to trial (see 7 superimposed examples for GC2 in boxed inset). The spike-lag, reflecting the difference in time to spiking between the two cells, was also long $(\sim 30 \mathrm{~ms})$. Vertical arrows indicate the start of EPSPs. $\boldsymbol{a}_{2}$, Distribution of spike-lags between granule cells for the pair in $\boldsymbol{a}_{\mathbf{1}}$. The plot was fitted to a Gaussian function with $\sigma_{\mathrm{GC}-\mathrm{GC} \text { spike-lag }}=25 \mathrm{~ms} . \boldsymbol{b}_{\mathbf{1}}, \boldsymbol{b}_{\mathbf{2}}$, During patterned ON stimulation, the spike-lag between granule cells was much shorter $(\sim 2 \mathrm{~ms})$. The large boxed inset ( $\boldsymbol{b}_{1}$, bottom left) shows the entire responses for $\mathrm{GC} 1$ and $\mathrm{GC}$, from which the selected segments were taken. $c$, Plot relating the between-granule cell spike-lags $\left(\sigma_{\mathrm{GC}-\mathrm{GC} \text { spike-lag }}\right)$ to the variations in spike delays in single granule cells $\left(\sigma_{\mathrm{GC} \text { spike-delay }}\right)$. Data reflect eight pair recordings made in response to $\mathrm{GCL}$ (circles) or patterned $\mathrm{ON}$ (squares) stimulation. All data points lie near the diagonal line, reflecting unity, consistent with the idea that the precision of synchronized spiking in granule cell pairs is determined by the jitter in single-cell spike delays. In these comparisons, the $\sigma_{\mathrm{GC}}$ spike-delay values were meant to reflect approximations, because the distributions of spike delays in single granule cells were not strictly Gaussian, tending to be skewed slightly toward smaller values. Stim,

conditions induce synchronized spiking on a time scale of 3-4 $\mathrm{ms}$, whereas slow NMDA receptors drive synchrony that is sixfold less precise under static conditions.

In other brain circuits that show gamma activity, the bestestablished mechanism for synchronizing GABAergic interneurons is through direct electrical and/or GABAergic synaptic interconnections (Whittington et al., 1995; Galarreta and Hestrin, 1999; Gibson et al., 1999; Tamás et al., 2000; Hormuzdi et al., 

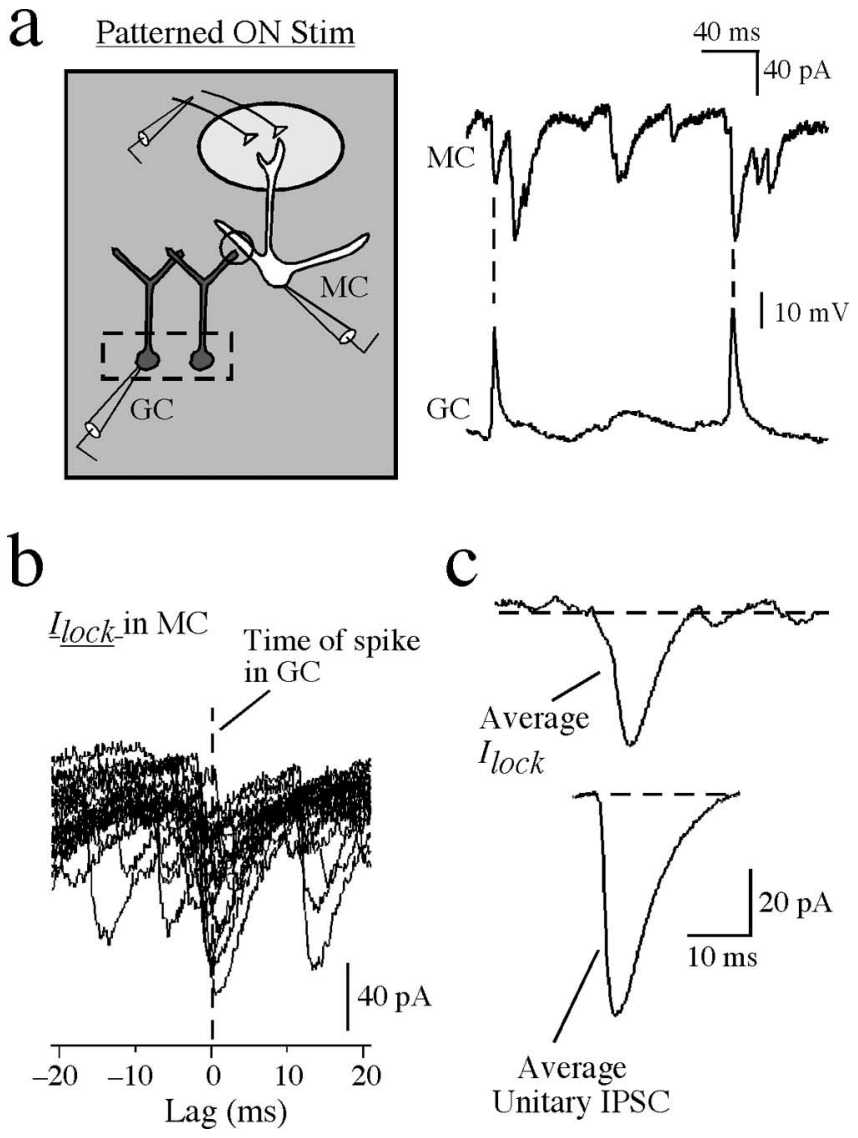

Figure 8. GABA release from granule cells during dynamic stimulation. $\boldsymbol{a}$, GABA release kinetics were determined from granule/mitral cell pair recordings, by aligning IPSCS in the mitral cell (top trace) to spikes in the granule cell (bottom trace). Note that in this experiment, the test mitral cell did not form direct synaptic connections to the test granule cell (diagram on the left) but instead was connected to granule cell(s) that were synchronized to the test granule cell. $\boldsymbol{b}, \boldsymbol{c}$, The current in the mitral cell (I lock) time-locked to the granule cell spike was very fast. $\boldsymbol{b}$ shows 20 superimposed examples, whereas $\boldsymbol{c}$ compares the average $I_{\text {lock }}$ and the unitary IPSC recorded in the same mitral cell (average of 35). GC, Granule cell; MC, mitral cell.

2001; Cunningham et al., 2003; Traub et al., 2004). Although there is evidence that fast AMPA receptor-mediated EPSPs can contribute to gamma activity in some cases (e.g., hippocampal CA3) (Fisahn et al., 1998; Mann et al., 2005), the present study of bulb granule cells provides the first direct evidence using pair-cell recordings that GABAergic interneurons can be synchronized by fast excitatory inputs, in the absence of significant electrical or GABAergic interconnections (but see Reyher et al., 1991). A reasonable question then is what might make granule cells different from interneurons in many other circuits, allowing them to be synchronized "indirectly" by mitral cell excitatory inputs? Part of the answer may be related to the specific connectivity and response profiles of mitral cells. Mitral cells are organized into discrete glomerular units, each with $\sim 25$ cells, and studies in slices have shown that direct excitatory interactions can drive both concerted slow depolarizations and rapid time-scale synchrony within these mitral cells (Carlson et al., 2000; Schoppa and Westbrook, 2001, 2002; Urban and Sakmann, 2002; Christie et al., 2005; Christie and Westbrook, 2006). Thus, during dynamic stimulation, granule cells likely receive EPSPs from a large network of highly active and synchronized mitral cells in close spatial proximity.

Most discussions of functions for gamma activity in the bulb focus on IPSP-driven synchronized spiking in mitral cells and its possible impact on cortical integration of olfactory information (Mori et al., 1999; Laurent et al., 2001; Brody and Hopfield, 2003; Davison et al., 2003; Lledo et al., 2005). The mechanisms described here that synchronize granule cells likely contribute to synchronized spiking in mitral cells, because the resulting tightly coordinated GABA release would cause large, fast-decaying synchronized IPSPs in mitral cells. The details of the relationship between granule cell synchrony and mitral cell spike output may, however, be complex. Based on the studies here, one interesting possibility is that synchrony could depend on the strength of network stimulation and its effect on $I_{\mathrm{A}}$ channels that determine whether fast AMPA or slow NMDA receptors drive granule cell activation. Whereas AMPA receptors drive fast synchronization under conditions of strong dynamic network stimulation, more moderate stimuli that fail to inactivate $I_{\mathrm{A}}$ channels could result in desynchronized NMDA receptor-dependent excitation of granules cells and reduced synchronization of mitral cells. Such a mechanism, operating under natural conditions, may help the cortex differentiate inputs arising from bulb regions that are strongly versus weakly activated by odor.

\section{Summary: a model for gamma frequency activity in the olfactory bulb}

The findings in this study, together with previous work, lead to the following model for how gamma activity is generated in the bulb. With each inspiration, activity begins when glutamate released from $\mathrm{ON}$ axons causes slow depolarizations within mitral cell networks. These depolarizations, which are $\sim 10 \mathrm{mV}$ (Schoppa and Westbrook, 2001; Margrie and Schaefer, 2003), bring mitral cells from their resting potential (approximately $-55 \mathrm{mV}$ ) (Cang and Isaacson, 2003) to near spike threshold (approximately $-45 \mathrm{mV}$ ). The resulting spiking in mitral cells leads to synchronous, AMPA/kainate receptor-dependent excitation of granule cells that receive divergent inputs from a single mitral cell or, possibly, a synchronous group of mitral cells. The synchronized granule cells, in turn, synchronize mitral cells through GABAergic outputs. The rapid back-and-forth interplay between synchronized mitral cells and granule cells would persist for as long as mitral cells are depolarized during inspiration. The exact kinetics of this interplay could reflect both the duration of the excitatory and inhibitory synaptic responses (both estimated to be $\sim 10 \mathrm{~ms}$ in the studies here), as well as intrinsic currents in participating neurons (Desmaisons et al., 1999; Egger et al., 2003).

\section{References}

Adrian ED (1950) The electrical activity of the mammalian olfactory bulb. Electroencephalogr Clin Neurophysiol 2:377-388.

Barrett EF, Stevens CF (1972) The kinetics of transmitter release at the frog neuromuscular junction. J Physiol (Lond) 227:691-708.

Bartos M, Vida I, Frotscher M, Meyer A, Monyer H, Geiger JR, Jonas P (2002) Fast synaptic inhibition promotes synchronized gamma oscillations in hippocampal interneuron networks. Proc Natl Acad Sci USA 99:13222-13227.

Brody CD, Hopfield JJ (2003) Simple networks for spike-timing-based computation, with application to olfactory processing. Neuron $37: 843-852$.

Cang J, Isaacson JS (2003) In vivo whole-cell recording of odor-evoked synaptic transmission in the rat olfactory bulb. J Neurosci 23:4108-4116.

Carleton A, Petreanu LT, Lansford R, Alvarez-Buylla A, Lledo PM (2003) Becoming a new neuron in the adult olfactory bulb. Nat Neurosci 6:507-518.

Carlson GC, Shipley MT, Keller A (2000) Long-lasting depolarizations in mitral cells of the rat olfactory bulb. J Neurosci 20:2011-2021.

Chen WR, Xiong W, Shepherd GM (2000) Analysis of relations between NMDA receptors and GABA release at olfactory bulb reciprocal synapses. Neuron 25:625-633. 
Christie JM, Westbrook GL (2006) Lateral excitation within the olfactory bulb. J Neurosci 26:2269-2277.

Christie JM, Bark C, Hormuzdi SG, Helbig I, Monyer H, Westbrook GL (2005) Connexin36 mediates spike synchrony in olfactory bulb glomeruli. Neuron 46:761-772.

Cunningham MO, Davies CH, Buhl EH, Kopell N, Whittington MA (2003) Gamma oscillations induced by kainate receptor activation in the entorhinal cortex in vitro. J Neurosci 23:9761-9769.

Davison AP, Feng J, Brown D (2003) Dendrodendritic inhibition and simulated odor responses in a detailed olfactory bulb network model. J Neurophysiol 90:1921-1935.

Desmaisons D, Vincent JD, Lledo PM (1999) Control of action potential timing by intrinsic subthreshold oscillations in olfactory bulb output neurons. J Neurosci 19:10727-10737.

Egger V, Svoboda K, Mainen ZF (2003) Mechanisms of lateral inhibition in the olfactory bulb: efficiency and modulation of spike-evoked calcium influx into granule cells. J Neurosci 23:7551-7558.

Fisahn A, Pike FG, Buhl EH, Paulsen O (1998) Cholinergic induction of network oscillations at $40 \mathrm{~Hz}$ in the hippocampus in vitro. Nature 394:186-189.

Freeman WJ (1972) Measurement of oscillatory responses to electrical stimulation in olfactory bulb of cat. J Neurophysiol 35:762-779.

Friedman D, Strowbridge BW (2003) Both electrical and chemical synapses mediate fast network oscillations in the olfactory bulb. J Neurophysiol 89:2601-2610.

Fuchs EC, Doheny H, Faulkner H, Caputi A, Traub RD, Bibbig A, Kopell N, Whittington MA, Monyer H (2001) Genetically altered AMPA-type glutamate receptor kinetics in interneurons disrupt long-range synchrony of gamma oscillation. Proc Natl Acad Sci USA 98:3571-3576.

Galan RF, Fourcaud-Trocme N, Ermentrout GB, Urban NN (2006) Correlation-induced synchronization of oscillations in olfactory bulb neurons. J Neurosci 26:3646-3655.

Galarreta M, Hestrin S (1999) A network of fast-spiking cells in the neocortex connected by electrical synapses. Nature 402:72-75.

Gibson JR, Beierlein M, Connors BW (1999) Two networks of electrically coupled inhibitory neurons in neocortex. Nature 402:75-79.

Halabisky B, Friedman D, Radojicic M, Strowbridge BW (2000) Calcium influx through NMDA receptors directly evokes GABA release in olfactory bulb granule cells. J Neurosci 20:5124-5134.

Hormuzdi SG, Pais I, LeBeau FE, Towers SK, Rozov A, Buhl EH, Whittington MA, Monyer H (2001) Impaired electrical signaling disrupts gamma frequency oscillations in connexin 36-deficient mice. Neuron 31:487-495.

Isaacson JS, Strowbridge BW (1998) Olfactory reciprocal synapses; dendritic signaling in the CNS. Neuron 20:749-761.

Jonas P, Spruston N (1994) Mechanisms shaping glutamate-mediated excitatory postsynaptic currents in the CNS. Curr Opin Neurobiol 4:366-372.

Kashiwadani H, Sasaki YF, Uchida N, Mori K (1999) Synchronized oscillatory discharges of mitral/tufted cells with different molecular receptive ranges in the rabbit olfactory bulb. J Neurophysiol 82:1786-1792.

Koike-Tani M, Saitoh N, Takahashi T (2005) Mechanisms underlying developmental speeding in AMPA-EPSC decay at the calyx of Held. J Neurosci 25:199-207.

Lagier S, Carleton A, Lledo PM (2004) Interplay between local GABAergic interneurons and relay neurons generates $\gamma$ oscillations in the rat olfactory bulb. J Neurosci 24:4382-4392.

Laurent G, Stopfer M, Friedrich RW, Rabinovich MI, Volkovskii A, Abarbanel HD (2001) Odor encoding as an active, dynamical process: experiments, computation, and theory. Annu Rev Neurosci 24:263-297.
Lledo PM, Gheusi G, Vincent JD (2005) Information processing in the mammalian olfactory system. Physiol Rev 85:281-317.

Mann EO, Suckling JM, Hajos N, Greenfield SA, Paulsen O (2005) Perisomatic feedback inhibition underlies cholinergically induced fast network oscillations in the rat hippocampus in vitro. Neuron 45:105-117.

Margrie TW, Schaefer AT (2003) Theta oscillation coupled spike latencies yield computational vigour in a mammalian sensory system. J Physiol (Lond) 546:363-374.

Matsutani S, Yamamoto N (2004) Postnatal development of dendritic spines on olfactory bulb granule cells in rats. J Comp Neurol 473:553-561.

Montague AA, Greer CA (1999) Differential distribution of ionotropic glutamate receptor subunits in the rat olfactory bulb. J Comp Neuro 405:233-246.

Mori K, Nagao H, Yoshihara Y (1999) The olfactory bulb: coding and processing of odor molecule information. Science 286:711-715.

Pressler RT, Strowbridge BW (2006) Blanes cells mediate persistent feedforward inhibition onto granule cells in the olfactory bulb. Neuron 49:889-904.

Rall W, Shepherd GM (1968) Theoretical reconstruction of field potentials and dendrodendritic synaptic interactions in the olfactory bulb. J Neurophysiol 31:884-915.

Reyher CK, Lubke J, Larsen WJ, Hendrix GM, Shipley MT, Baumgarten HG (1991) Olfactory bulb granule cell aggregates: morphological evidence for interperikaryal electrotonic coupling via gap junctions. J Neurosci 11:1485-1495.

Schoppa NE (2006) Synchronization of olfactory bulb mitral cells by precisely timed inhibitory inputs. Neuron 49:271-283.

Schoppa NE, Westbrook GL (1999) Regulation of synaptic timing in the olfactory bulb by an A-type potassium current. Nat Neurosci 2:1106-1113.

Schoppa NE, Westbrook GL (2001) Glomerulus-specific synchronization of mitral cells in the olfactory bulb. Neuron 31:639-651.

Schoppa NE, Westbrook GL (2002) AMPA autoreceptors drive correlated spiking in olfactory bulb glomeruli. Nat Neurosci 5:1194-1202.

Schoppa NE, Kinzie JM, Sahara Y, Segerson TP, Westbrook GL (1998) Dendrodendritic inhibition in the olfactory bulb is driven by NMDA receptors. J Neurosci 18:6790-6802.

Shepherd GM, Chen WR, Greer CA (2004) Olfactory bulb. In: The synaptic organization of the brain (Shepherd GM, ed), pp 165-216. New York: Oxford UP.

Tamás G, Buhl EH, Lorincz A, Somogyi P (2000) Proximally targeted GABAergic synapses and gap junctions synchronize cortical interneurons. Nat Neurosci 3:366-371.

Traub RD, Bibbig A, LeBeau FE, Buhl EH, Whittington MA (2004) Cellular mechanisms of neuronal population oscillations in the hippocampus in vitro. Annu Rev Neurosci 27:247-278.

Traub RD, Whittington MA, Colling SB, Buzsaki G, Jefferys JG (1996) Analysis of gamma rhythms in the rat hippocampus in vitro and in vivo. J Physiol (Lond) 493:471-484.

Urban NN, Sakmann B (2002) Reciprocal intraglomerular excitation and intra- and interglomerular lateral inhibition between mouse olfactory bulb mitral cells. J Physiol (Lond) 542:355-367.

Whittington MA, Traub RD, Jefferys JG (1995) Synchronized oscillations in interneuron networks driven by metabotropic glutamate receptor activation. Nature 373:612-615.

Youngentob SL, Mozell MM, Sheehe PR, Hornung DE (1987) A quantitative analysis of sniffing strategies in rats performing odor detection tasks. Physiol Beh 41:59-69. 